\title{
A glass half full look at the brazilian data protection authority
}

\section{Observando a autoridade nacional de proteção de dados brasileira na perspectiva do copo "meio cheio"}

(iD) Leonardo Parentoni ${ }^{1}$

\begin{abstract}
In any data protection system, the regulatory institution - called the National Data Protection Authority - plays a substantial role. In Brazil, this institution was created differently from what had originally been expected. Therefore, the legal literature started to criticize it and to doubt its ability to satisfactorily exercise its regulatory powers. Even before the Brazilian general data protection act came into effect, a major opinion was formed around the idea that, in its current structure, the Brazilian Data Protection Authority ${ }^{2}$ would fail. This is the main research problem that the author will further explore in the text, aiming at providing a different view on the subject. Amid the uncertainty, he opted for looking at the glass "half full" instead of seeing it as "half empty". He highlights that even in its current format the BDPA is remarkable progress and could be very useful to the Brazilian personal data protection system. After all, more important than the structure of the regulatory body are its capacities and how they will be exercised in practice. To provide this text with a scientific basis, the author conducted a structuralist analysis drawing a comparison between the Brazilian Data Protection Authority and the equivalent institution in Uruguay (URCDP), which has a very similar structure and has been carrying
\end{abstract}

\footnotetext{
1 Doutor em Direito pela USP. Mestre em Direito Empresarial pela UFMG. Especialista em Direito Processual Civil pela UnB. Graduado em Direito pela UFMG. Procurador Federal de Categoria Especial - AGU. Professor Adjunto da Faculdade de Direito da UFMG e Titular do IBMEC/MG. Fundador e Coordenador da área de concentração em Direito, Tecnologia e Inovação na Pós-Graduação da Faculdade de Direito da UFMG. Fundador e Conselheiro Científico do Centro de Pesquisa em Direito, Tecnologia e Inovação DTIBR (www.dtibr.com). Membro do Conselho Nacional de Proteção de Dados Pessoais e da Privacidade. Ex-membro de Comissões do Conselho Nacional de Justiça, do Conselho da Justiça Federal, da Procuradoria-Geral Federal e da OAB/MG. Pesquisador Visitante na Universidade do Texas em Austin/USA e na Agência de Proteção de Dados do Uruguai. Parceiro tecnológico estratégico na Universidade de Tecnologia de Sydney. Mentor de Equipe no Programa Law Without Walls, LWOW/USA. Áreas de atuação: 1) Direito, Tecnologia e Inovação; 2) Direito Societário; 3) Análise Empírica do Direito (Empirical Legal Studies, ELS). Researcher ID: N-5627-2015. ORCID: 0000-0002-3593-2831.

2 In Portuguese, this institution is called Autoridade Nacional de Proteção de Dados - ANPD. Hereiafter in this text it will be referred to as Brazilian Data Protection Authority - BDPA.
} 
out its duties with success for over a decade. In the end, it was possible to demonstrate that the initial structure of the BDPA is not a barrier that could prevent it from carrying on its duties. Therefore, it is prudent to trust the BDPA and monitor how it will operate.

Keywords: Privacy. Personal Data Protection. Brazilian Data Protection Authority - BDPA. Uruguay Data Protection Authority - URCDP.

Resumo: Em qualquer sistema de proteção de dados pessoais, a instituição reguladora - em vários países denominada Autoridade Nacional de Proteção de Dados (ANPD) - desempenha papel destacado. No Brasil, esta instituição foi criada de forma diferente do previsto. Por isso, a literatura especializada passou a criticá-la e a duvidar de sua aptidão para exercer satisfatoriamente o papel de órgão regulador. Antes mesmo da entrada em vigor da lei geral de proteção de dados pessoais, formou-se opinião majoritária de que, no formato atual, a ANPD iria fracassar. Este é o principal problema de pesquisa que o autor irá explorar no texto, procurando fornecer uma perspectiva diferente sobre o tema. Diante da incerteza, optou-se por enxergar o copo "meio cheio" ao invés de "meio vazio". Ou seja, considera-se que mesmo no atual formato a ANPD é sim um grande avanço e pode ser muito útil ao sistema brasileiro de proteção de dados. Afinal, mais importante do que a estrutura são as funções do órgão regulador e como elas serão exercidas na prática. Para embasar cientificamente o texto, realizou-se uma análise estruturalista comparando a ANPD brasileira com a instituição equivalente do Uruguai (URCDP), que tem formato semelhante e vem atuando com sucesso há mais de uma década. Ao final, foi possível demonstrar que a estrutura inicial da ANPD não é, por si só, um óbice intransponível ao bom exercício de suas funções. É preciso dar um voto de confiança à ANPD e monitorar como ela irá de fato desempenhar as suas atribuições.

Palavras-chave: Privacidade. Proteção de Dados Pessoais. Autoridade Nacional de Proteção de Dados (ANPD). Autoridade Uruguaia de Proteção de Dados (URCDP).

Data de submissão do artigo: Junho de 2020

Data de aceite do artigo: Julho de 2021 


\section{Introduction: The Bdpa And Its Mission}

In every personal data protection system, there must be an institution responsible for its regulation which plays a major role ${ }^{3}$. In some countries, this institution accumulates the protection of personal data with other assignments, eventually very different ones. This is the case for the Federal Trade Commission - FTC in the United States of America, whose main mission is to "protect consumers and competition"4, but also to protect personal data (privacy)5. On the other hand, there are countries in which a public institution is specifically in charge of protecting personal data. That is what happens in the member's states of the European Union since its Charter of Fundamental Rights (CFREU Section 8, 3) considers as mandatory the existence of an independent authority for this purpose in each country, as well as a European agency for harmonizing this theme inside the Union6.

In the Brazilian legal tradition, personal data protection has been sparsely addressed in various laws, from the Brazilian Telecommunications Code of the $60 \mathrm{~s}$ and its decree to more recent laws such as the Brazilian Consumer Defense Code (CDC) and the "Positive Credit Reporting Act". In this context, the institution responsible for overseeing market compliance with each of these laws also acted partially in the mission of protecting personal data. But there was no authority in place exclusively focused on this subject.

The legal landscape has deeply changed with the advent of Law n 13709/2018 - Brazilian General Data Protection Law (BGDPL), which having been strongly influenced by the European

3 (DONEDA, 2019, p. 471-475).

4 (THE UNITES STATES OF AMERICA - FEDERAL TRADE COMMISSION, 2019/a, p. 01).

5 An aspect reinforced by the fact that in July 2019, the FTC applied to Facebook the largest fine in history, amounting to USD 5 billion for violating previous recommendations of FTC itself, dating back to 2012, regarding measures that should have been adopted by Facebook for greater protection of US users personal data of. (THE UNITES STATES OF AMERICA - FEDERAL TRADE COMMISSION, 2019/b, p. 01).

6 For a detailed study on the similarities and cultural differences between the US and the EU in terms of personal data protection, see the text by James Whitman: (WHITMAN, 2004). 
A glass half full look at the brazilian data protection authority Leonardo Parentoni

model (General Data Protection Regulation - GDPR) ${ }^{7}$, has created the Brazilian Data Protection Authority (BDPA) ${ }^{8}$, a public institution dedicated specifically to "ensure the protection of personal data under the law" (Law Section 55-J, I). In other words, Brazil has finally come to own a central regulatory institution such as the European model9.

It turns out that there is a lot of suspicion regarding the potential of the BDPA to effectively act in a technical, impartial and efficient manner. This is the main research problem that the author will further explore in the text, aiming at providing a different - and more optimistic - view on the subject, by drawing a comparative analysis between the BDPA and the corresponding institution from Uruguay - called URCDP, due to their structural similarities.

\section{Brief Legislative History Of The Bdpa}

The original House of Representatives Bill n 4060/2012, which would later become the BGDPL, did not foresee the creation of the BDPA. It was first outlined in the Executive Bill n $5276 / 2016$ (Section 53), as an administrative body. As such, it was not a legal entity nor had its budget or personnel. However, still during the legislative process, a parliamentary amendment proposed to change its format to a regulatory agency by the terms of Section 55 of Bill $n^{\circ}$ 53/2018, a movement encouraged by the opinion of legal experts, according to whom this new structure would be the only one able to provide the authority with the independence to perform its regulatory duties,

\footnotetext{
7 The justification of the Law $n^{\circ} 4060 / 2012$ did not explicitly mention the GDPR's influence. However, such aspect has become clear in later bills such as Law $n^{\circ}$ 5276/2016, which stated that: "the debate on privacy and personal data dealt with in this Preliminary Draft Bill was also heavily influenced by the international context." (BRAZIL - CÂMARA DOS DEPUTADOS, 2016). 8 The troubled legislative history that culminated on the creation of the BDPA will be addressed in the next section. 9 Even though there are substantial differences between the format of the BDPA and its European counterpart, this aspect goes beyond the purpose of this study.
} 
A glass half full look at the brazilian data protection authority

mirroring similar international organizations ${ }^{10}$. However, due to this new structure the creation of the authority was vetoed by the President based on two grounds: 1) a parliamentary amendment could not lead to an increase in expenses for bills proposed by the Executive ${ }^{11}$; and 2) Brazilian laws forbid the proposal of bills that could increase current expenditures during the last few months of a presidential term. ${ }^{12}$ The conjuncture of a severe economic crisis in the country (demanding great efforts to contain public spending and reduce staff) has significantly contributed to the veto. As a consequence of this veto, the BGDPL finally published on August 14,2018 , did not foresee the creation of the BDPA.

To fill that gap, on December 27, 2018, the Executive itself has handled the presentation of the Provisional Measure $n^{\circ} 869 / 2018$, which had as one of its core aspects the creation of the BDPA, structured as an administrative body, without increasing expenses (Section 55-A), in the same way as it was originally outlined in 2016. Once again, an intense debate over this structure took place. Many voices highlighted its possible shortcomings, especially the lack of independence when exercising regulatory duties against the State itself. Shortly after, on July 18, 2019, Law no 13844/2019 (Section 2: $\mathrm{VI}$ and Section 12) has formally inserted the BDPA into the structure of the Presidency as an administrative body. This structure was finally consolidated on July 8, 2019, when the Provisional Measure $\mathrm{n}^{\circ}$ 869/2018 was converted into Law $n^{\circ} 13853 / 2019$, keeping the BDPA as an administrative body inside the structure of the Presidency, in accordance with the previous provisions.

These events, however, did not mean that the BDPA was fully created and able to perform its duties. Many essential aspects were still missing even after the definition of its legal structure. Starting with the nomination of the first directors, who will oversee

\footnotetext{
10 (DONEDA, 2006, p. 385-386): “The use of an administrative authority for the protection of personal data, in the model of an independent authority, is a trend strongly rooted in some legal systems. After its conception and adoption in countries such as Germany and Sweden, its creation was deemed mandatory to all countries members of the European Union (...) turning it into a core feature of the so-called 'European model' of personal data protection. It is not, however, a phenomenon restricted to the geographical and political European spaces, since similar organizations can be found in countries such as Argentina, Australia, Canada, Japan, Israel, Hong Kong, New Zealand and Taiwan." 11 (BRAZIL - PRESIDÊNCIA DA REPÚBLICA, 2018).

12 For example, Section 42 of the Brazilian Law of Fiscal Responsibility (Supplementary Law $\left.n^{\circ} 101 / 2000\right)$ and Section 359-C of the Brazilian Criminal Code (Decree-Law n² 2848/1940).
} 
A glass half full look at the brazilian data protection authority

the BDPA during its first years of existence and who will carry the burden of effectively establishing this administrative body. The President of the Republic only nominated the first five directors on October 15th, 2020, and a few days after they were all submitted to the confirmation hearing before the Senate (called "sabatina") and approved. Finally, on November 6th, 2020, all of them were invested in their functions and started to work. That is, therefore, the official date of birth of the BDPA.

Therefore, the BDPA was created in December 2018 but it became operative only in November 2020, almost two years after. Quite a long road has been traveled so far and much more needs to go through before we can effectively evaluate its actions and decisions.

This brief history demonstrates that the creation of the BDPA was one of or the most - if not the most - sinuous aspects of the legislative process that gave rise to the BGDPL. Besides those many legislative turnarounds, the structure of the BDPA was also subject to an intense discussion, on both public and private forums, as to which structure it should have. In the end, the Executive's position to create the authority as an administrative body inside the structure of the Presidency without incurring additional costs has prevailed. The government is fully aware that this structure is not the ideal model but the only one possible in the current context of the country. So much so that BGDPL itself (Section 55-A, 1st and 2nd Paragraphs) recognize this structure as transient, providing that it should be re-evaluated after two years for a possible conversion into a legal personhood in the form of an authentic regulatory agency with its budget and personnel.

\section{Criticism About The Current Structure Of The Bdpa}

The choice of structuring the BDPA as an administrative body instead of a special regime autarchy (an agency) was subjected to 
A glass half full look at the brazilian data protection authority

intense criticism from both the legal community and the press 13. Some of this criticism are briefly listed below. Even though the author does not agree with all of them, he considers it important to describe these arguments as a basis for the antithesis built in the following topics.

The first criticism is that the BDPA was not structured as a regulatory agency. This aspect is reinforced by the fact that the BDPA is not included in the 2nd Section of Law n ${ }^{\circ} 13848 / 2019$, which lists some of the main regulatory entities operating in the country14. As a result, the "European model" that inspired the BGDPL was left aside15. Moreover, the rules of Law $n^{\circ} 13848 / 2019$ on interaction with other regulatory agencies and public bodies do not apply to the BDPA. These rules could be of paramount importance in complementing the few dispositions of the BGDPL around this subject, helping to solve potential conflicts of attribution.

The second criticism is related to the first. Had it been structured as an autarchy, the BDPA would have a "decentralized administrative and financial management" according to the Decree-Law n² 200/1967, Section 5, I. However, being structured as an administrative body resulted in the lack of a budget of its own, remaining linked to - and dependent on - the general budget of the Presidency. Especially because the other sources of income provided for the BDPA on Section 55 of the BGDPL tend to be insufficient. This could jeopardize its financial autonomy. This aspect is aggravated by the fact that the BDPA also may not collect fees for services rendered such as the approval of binding corporate rules and other documents.

A third criticism says that the current structure of the BDPA makes it harder to organize its staff with specialized personnel. After all, to achieve greater specialization it would be advisable to create a career of its own, made up of members selected

\footnotetext{
13 Summarizing these arguments: (BIONI, 2019).

14 Nor was it structured as a regulatory agency in the BGDPL, what could make applicable the provision of the 2nd Section, Sole Paragraph, of Law n' 13848/2019: "Except from what is envisaged in the specific legislation, the provisions of this law should be applied to special autarchies characterized in terms of such law as regulatory agencies and created from its effective date." 15 (SOPRANA, 2018, p. 01): "Provisional Measure 869 founds an administrative body connected to the Presidency of the Republic and not an independent authority as provided in the original bill. (...) Representatives of the Academy and civil society involved in the debate also criticized the BDPA's connection to the Executive." See also Section 52 of the GDPR.
} 
A glass half full look at the brazilian data protection authority Leonardo Parentoni

through a specific public tender that would test knowledge in the field of personal data protection. However, this is definitely not going to happen since the staff of the BDPA will be composed of public employees from other fields, already admitted into the administration, in addition to those appointed to positions of trust.

The fourth criticism concerns the BDPA's possible lack of technical autonomy because its directors could suffer all sorts of political pressure, especially when the authority has to exercise its regulatory duties against the government itself16.

Even if all this criticism is overcome and the current structure of the BDPA is eventually considered acceptable, one more question remains: where to allocate it? Some scholars suggested17 placing this new administrative body within the Ministry of Justice, similar to what has been done to CADE (The Brazilian Administrative Council for Economic Defense) during its first years. However, the choice to allocate it within the Presidency of the Republic prevailed.

All this criticism led to the conclusion that in its current structure the BDPA would lack the independence to satisfactorily perform its regulatory duties, especially to supervise the government itself18. They can be resumed as follows:

"It is, therefore, of high regulatory hazard to institutionalize the BDPA with a reduced structure, created under the political enunciation of 'absence of increased spending' with a command for implementing minimum regulation, drawn to hold limited autonomy, as well as limited technical, administrative and financial independence, whether in relation to private regulated entities but mainly in relation to the State." ${ }^{\prime 19}$

\footnotetext{
16 (VALENTE, 2019, p. 01): "The Secretary of State for Consumer Defense of the Ministry of Justice, Luciano Benetti Timm, has expressed his concerns about the risks of capture of the agency."

17 (VENTURA, 2019, p. 03): "Another point that has resulted in discussions and controversies was about which part of the government would host the BDPA. Officially the Ministry of Justice has manifested interest in encompassing the authority, arguing that among other reasons that Ministry has the successful experience of CADE, the Administrative Council of Economic Defense, which has emerged in the MJ and today is completely independent.

18 (PSCHEIDT, 2019, p. 02): "The agency suffers direct political and partisan influence because it is connected and committed to government and political party plans. (...) With the creation of a 'simple' agency, the Executive will have full regulatory control, which will establish guidelines on Data Protection according to the governmental plan. It will reduce some frictions but also will make any future regulation even more politically affected, which raises great concern."

19 (VASCONCELOS; DE PAULA, 2019, p. 735): “É, portanto, de elevado risco regulatório a instituição de uma ANDP com estrutura reduzida, criada sob o enunciado político de ausência de 'aumento de despesa', com comando de regulação de 'intervenção mínima', desenhada para ter limitada autonomia e independência técnica, administrativa e financeira, seja com relação aos agentes privados regulados, mas, sobretudo, com relação ao Poder Público."
} 
A glass half full look at the brazilian data protection authority Leonardo Parentoni

Some of these arguments are not technically grounded, while others have been overcome by changes that occurred during the legislative process of converting the Provisional Measure $n^{\circ} 869 / 2018$ into law. Furthermore, even the pertinent criticism does not mean that the BDPA is doomed to fail. After all, just as important as its structure - if not far more important - is how it will exercise its regulatory powers ${ }^{20}$.

\section{Why The Comparison With Uruguay?}

It is notorious that Brazil and Uruguay are countries substantially different in many aspects: territorial extent, number of inhabitants, gross domestic product, climate, vegetation, official language, etc ${ }^{21}$. So what would be the reason for comparing them? The answer is that the Uruguayan Data Protection Authority (URCDP) has a structure very similar to the Brazilian one. Moreover, the Uruguayan URCDP has been very successful in carrying out its regulatory duties. Thus, it is possible to learn from the Uruguayan experience and extract useful insights for Brazil.

First, Uruguay already has in place a specific law addressing personal data protection since 2004 (Ley $n^{\circ}$ 17838/2004)22. And since 2008 it has adopted a General Law on the subject (Ley $n^{\circ}$ 18331/2008)23. Therefore, Uruguay has regulated personal data protection with specific laws more than a decade before Brazil.

\footnotetext{
20 (BOBBIO, 2007, p. 112): "[functional analysis] here understood as a general theory that seeks the characterization of element of law not in the specificity of the structure, as had occurred so far by some of the greatest theoretical scholars, but in the specificity of the function (...)."

21 For detailed statistics regarding Uruguay, it is recommended the reading of: (URUGUAY - INSTITUTO NACIONAL DE ESTADÍSTICA, 2019).

22 “Artículo $1^{\circ}$.- El presente Título tiene por objeto regular el registro, almacenamiento, distribución, transmisión, modificación, eliminación, duración, y en general, el tratamiento de datos personales asentados en archivos, registros, bases de datos, u otros medios similares autorizados, sean éstos públicos o privados, destinados a brindar informes objetivos de carácter comercial." 23 "Artículo 3. Ambito objetivo. El régimen de la presente ley será de aplicación a los datos personales registrados en cualquier soporte que los haga susceptibles de tratamiento, y a toda modalidad de uso posterior de estos datos por los ámbitos público o privado."
} 
A glass half full look at the brazilian data protection authority Leonardo Parentoni

Secondly, Uruguay has obtained an adequacy decision 24 from the European Union in August 2012, after proving that the country provides an adequate level of protection for data transfers in its legislative system similar to those prevailing in Europe until Directive 95/46/CE. As much as having the URCDP as an independent authority25. In other words, while Brazil is still working to harmonize with the European model26, Uruguay has already obtained official recognition in this regard. It is also worth mentioning that Uruguay was the first non-European country to accede to Treaty n ${ }^{\circ} 108 / 198127$ of the Council of Europe, in August 201328.

Uruguay is still the only South American State member of the Digital 9, a select group of 9 countries that call themselves "the world's most advanced digital nations"29. It was even chosen to host this group's annual meeting in 2019.

Finally, in 2019 a national survey noted that $92 \%$ of interviewees had access to the internet, as well as $100 \%$ of requirements to the Federal Administration can be initiated online, while $70 \%$ of them can be fully processed and solved in this manner. Even more surprising is the result that $53 \%$ of the population has affirmed to be completely aware of their data protection rights 30.

Those numbers illustrate the expressive results Uruguay has been reaping by investing in digital development. All of it, plus the

24 (TIKKINEN-PIRI; ROHUNEN; MARKKULA, 2018, p. 145): “The GDPR builds on DIR95 regarding the European Commission's possibility to make an adequacy decision about the level of data protection of a third country (or a territory or a processing sector in that country) or an international organization. To make the decision, the commission has to assess the level of protection regarding the rule of law, the independent supervisory authority and the international commitments entered into by the third country or the international organization. (...) If an adequacy decision has been made, a transfer may take place, and any further authorization to transfer is not required from the supervisory authority." Along the same lines: ((SARMENTO E CASTRO, 2005, p. 281).

25 THE EUROPEAN UNION - COMISSÃO EUROPEIA, 2012): “Section 1. For the purposes of Section 25, no. 2, of Directive 95/46/ $\mathrm{CE}$, it is considered that the Eastern Republic of Uruguay ensures an adequate level of protection for personal data transferred from the European Union." See also recital 10.

26 The European model of data protection works in fact as the standard model adopted by many countries (de facto standard). Some exceptions to this model are the United States, China and Russia.

(LYNSKEY, 2015, p. 41): "Data protection is one of the rare fields in which the EU could be said to exercise global regulatory supremacy; the EU rules have now been used as a blueprint for regulatory regimes across the Western world."

27 The Council of Europe is an international organization that promotes human rights including personal data protection: (COUNCIL OF EUROPE - COOPERAÇÃO INTERNACIONAL, 2019). It was responsible for the creation of Treaty 108 in January 1981 , the very first international treaty about personal data protection that was open to accession by interested countries, whether European or not. For further information, see: (TENE, 2013, p. 1221).

28 (COUNCIL OF EUROPE - CONVENTION FOR THE PROTECTION OF INDIVIDUALS WITH REGARD TO AUTOMATIC PROCESSING OF PERSONAL DATA, 1981).

(NOUGRÈRES, 2019, p. 578). “This converted Uruguay in the 45th country to be part of the Convention 108 and the first non-European to sign that convention."

29 (DIGITAL 9, 2019).

30 (URUGUAY - AGENCIA PARA EL DESARROLLO DEL GOBIERNO DE GESTIÓN ELECTRÓNICA Y LA SOCIEDAD DE LA INFORMACIÓN Y DEL CONOCIMIENTO, 2019). 
A glass half full look at the brazilian data protection authority

fact that its national authority is structured similarly to the BDPA, justifies the comparative analysis hereby conducted.

\section{Drawing A Comparison Between The Uruguayan Urcdp And The Brazilian Bdpa}

It is worth mentioning that the author does not mean to draw a complete analysis of comparative law. Instead, the aim is just to narrow down the scope of this research to a structuralist analysis intending to spot common institutional guarantees31 of the data protection authorities in Brazil and Uruguay. This kind of investigation is more qualitative than quantitative and can clarify what to expect from the Brazilian authority when it effectively starts to operate 32 .

The Uruguayan data protection authority is called Unidad Reguladora y de Control de Datos Personales (URCDP), which can be translated to the Unity of Regulation and Control of Personal Data. It is worth noting that the name does not even mention the term "authority" traditionally used in the European model.

Operating for over a decade, the URCDP has already achieved significant results33. Some information about its accomplishments are listed below.

Dozens of events to make people aware of their data protection rights have been put in place, involving varied audiences such as children, high school teachers, employees that work directly with personal data, public officers, and the elderly. Moreover, more than 1,800 consultations were answered in 2017 alone, of which 642 had been made in person, 692 by telephone, and 540 by e-mail. Online courses were offered on the website of the URCDP, as well as academic events hosting national and international specialists,

31 (MENDES, 2019, p. 142) “(...) institutional guarantees represent those juridical institutions created by and dependent on the legal framework."

32 (HOPT, 2009, p. 10): "Try to see what is useful for your own continent and for your country. This is the essence of Comparative Law: learning from others' mistakes and good experiences."

33 (URUGUAY - UNIDAD REGULADORA Y DE CONTROL DE DATOS PERSONALES, 2019/a). 
A glass half full look at the brazilian data protection authority Leonardo Parentoni

such as "charlas de café" (monthly meetings in which this author had the opportunity to participate in 2019). Regarding the regulatory activities 122 resolutions were issued in 2017 to implement legal provisions. Internationally the URCDP has participated in meetings of the Ibero-American Data Protection Network, of the InterAmerican Legal Committee of the Organization of American States (OAS), of the International Association of Privacy Professionals (IAPP) and of the Advisory Committee of Treaty $n^{\circ} 108 / 1981$ of the Council of Europe. Regarding the number of databases, from a total of 9000 databases registered until 2017 more than 150 were effectively audited that year alone, 30 of which were public, 13 controlled by individuals, 107 controlled by legal entities, and 1 controlled by a parastatal organization. From 2009 to 2017, more than 20 codes of conduct were reviewed and approved. Finally, regarding the sanctions in 20178 warnings and 17 fines were imposed.

After properly highlighting the positive numbers of the URCDP it is time to demonstrate how its structure and function are similar to the Brazilian authority.

The URCDP was created by the Uruguayan General Data Protection Law34 in 2008, as an administrative body inside the structure of the Agencia para el Desarrollo del Gobierno de Gestión Electrónicay la Sociedad de la Informacióny del Conocimiento (AGESIC), a governmental agency in charge of coordinating actions for the development of the "e-Government" in Uruguay35, according to

\footnotetext{
34 Ley n. 18.331/2008. Art. 31. “CAPITULO VII - ORGANO DE CONTROL. Artículo 31. Organo de Control. - Créase como órgano desconcentrado de la Agencia para el Desarrollo del Gobierno de Gestión Electrónica y la Sociedad de la Información y del Conocimiento (AGESIC), dotado de la más amplia autonomía técnica, la Unidad Reguladora y de Control de Datos Personales. Estará dirigida por un Consejo integrado por tres miembros: el Director Ejecutivo de AGESIC y dos miembros designados por el Poder Ejecutivo entre personas que por sus antecedentes personales, profesionales y de conocimiento en la materia aseguren independencia de criterio, eficiencia, objetividad e imparcialidad en el desempeño de sus cargos.

A excepción del Director Ejecutivo de la AGESIC, los miembros durarán cuatro años en sus cargos, pudiendo ser designados nuevamente. Sólo cesarán por la expiración de su mandato y designación de sus sucesores, o por su remoción dispuesta por el Poder Ejecutivo en los casos de ineptitud, omisión o delito, conforme a las garantías del debido proceso. Durante su mandato no recibirán órdenes ni instrucciones en el plano técnico."

35 For further reading on the Uruguayan initiative of an electronic government (e-government), see: (BRUNET, 2015).
} 
A glass half full look at the brazilian data protection authority Leonardo Parentoni

Section 72 of Law $n^{\circ} 17930 / 2005$. Hence, the URCDP is structured as an administrative body such as the Brazilian authority36.

Its internal structure comprehends a Board of Directors composed of 3 members. Therefore, even smaller than the equivalent structure of the BDPA, which has 5 Directors, according to Section 55-D, caput, of the BGDPL. Members of the Board of Directors at RCDP have a fixed mandate of 4 years admitting reelection. The same period is foreseen for directors of the BDPA as provided in Section 55-D, Third Paragraph of the BGDPL.

Besides, members of the Board of Directors at URCDP may only be compulsorily removed from their positions at the end of the mandate or by decision of the Executive, in case of ineptitude, omission or practice of illicit act, always respecting the due process of law. On that topic, the BDPA provides even more guarantees, since the definitive removal of its Directors may only occur based on "a final court decision or a dismissal decided in an administrative process" under Section 55-E, caput, of the BGDPL. Last but not least, the BDPA has an additional safeguard: the preventive removal of a Director can only be imposed by the President of the Republic himself/herself after the recommendation of a special committee, as stated in Section 55-E, 2nd Paragraph of the BGDPL. In other words, only the highest authority of the Executive can remove the Directors before a definitive administrative decision or a final judicial decision.

To continue, both URCDP and BDPA have technical and operative autonomy to exercise their regulatory powers, an aspect provided by law clearly and unambiguously (in Brazil according to Section 55$B$, caput, of the BGDPL). One of the most important consequences of this provision is the fact that decisions from the BDPA are definitive inside the public administration and cannot be subject to

\footnotetext{
36 (NOUGRÈRES, 2019, p. 573): “The URCDP is an autonomous administrative body from the Uruguayan agency who oversees the electronic government and have technical autonomy. It is positioned in the State chart and it is not subject to mandates or instructions from State powers.

The URCDP is run by a committee composed of three members: the Executive Director of the Uruguaian Agency for Electronic Government (or who he/she nominates) and two members nominated by the Executive Branchdue to their background, professional experience and knowledge about the subject, which shall ensure their independence, efficiency objectivity and imparciality to fulfill their duties. These member alternate annually to occupy the presidency of the URCDP. With the exception of the Executive Director, they last four years in their positions and can have their mandates renewed."
} 
A glass half full look at the brazilian data protection authority Leonardo Parentoni

an appeal that could bring them to the scrutiny of the President of the Republic37. Of course, they are still subject to judicial review, as are all administrative decisions.

It is well-known that there are laws that become repeatedly unobserved even though they are in force ("non-binding laws")38. However, it cannot be presumed that the technical and operative autonomy of the BDPA will suffer that sad end. On the contrary, the very purpose of law itself as a regulatory system for life in society mandates to presume that the law will be respected. Especially at the current moment, when the BDPA has not even started to operate, and therefore it is not yet possible to evaluate the technicality and impartiality of its decisions.

The attributions of the URCDP are also very similar to those of the Brazilian authority. For example, to develop guidelines, to consider petitions of data subjects, to conduct studies and educate the population, to regulate, to supervise and possibly to impose sanctions39.

To conclude it is worth mentioning that the author of this paper has visited the URCDP in 2019, as a guest researcher, when he heard in person one of the "mantras" of this regulatory body repeated by both late and current directors which is the fact that there has never been any political interference in their decisions. Amid the uncertainty, it seems better to look at the glass as "half full" instead of seeing it as "half empty". Therefore, instead of disbelieving the BDPA ab initio why not believe - and surveil for - that it indeed fulfills its capacities? After all, in law good faith is presumed, and bad faith must be evidenced.

\footnotetext{
37 (PFEIFFER, 2002, p. 458).

38 (RIPERT, 2002, p. 268): “The constant violation of law gets men used to consider that what is not respected is not respectable. Legal provisions fall into disuse or survive only at the expense of successive amendments. But by being constantly amended, it cannot acquire the prestige that turn institutions into long traditions. It is no longer respected by default. Moreover, the change of rules is many times expected. What was illegal yesterday becomes lawful a few months later."

39 For a detailed analysis of the URCDP's assignments and how they have been carried out since its creation, see: (URUGUAY - UNIDAD REGULADORA Y DE CONTROL DE DATOS PERSONALES, 2019/b, p. 97) “La URCDP ha desarrollado desde sus inicios una gestión enfocada en el cumplimiento de metas anuales - y en ocasiones quinquenales - asociadas a proyectos específicos vinculados a la promoción, difusión y evolución del derecho a la protección de datos personales."
} 


\section{Bdpa's Additional Guarantees And Some Questions Still Left Open}

Besides all the aspects already mentioned in the previous section, the BGDPL provides other guarantees to the BDPA, to equip it with enough instruments to perform its regulatory duties. Much of these guarantees were inserted during the legislative process of conversion of Provisional Measure $n^{\circ}$ 869/2018 into Law $n^{\circ} 13853 / 2019$. Therefore, they are subsequent to some of the criticism already mentioned and they were included in law precisely in response to these criticisms, to minimize the risks that had been identified.

Firstly, the role of the BDPA and its capacities was one of the most amended parts during the legislative process. While in Section 53 of Executive Bill $n^{\circ} 5276 / 2016$ (the first to propose the creation of the BDPA) there were only 13 capacities for that authority, in the conversion to Law $n^{\circ} 13853 / 2019$ these capacities were expanded up to 29 (BGDPL Section 55-J). In other words, its list of powers was more than doubled.

Another important amendment was the introduction of Section 55-D, 2nd Paragraph of the BGDPL, demanding that the nominees for the Board of Directors of the BDPA should be previously approved by the Senate in a confirmation hearing (called "sabatina" in Portuguese). A process stricter than, for example, the appointment of Ministers of State. The main reason for this rule is to provide the Senate with an opportunity to avoid candidates nominated by the President of the Republic based only in political convenience, when proved that the nominees do not have the proper qualifications. Subsequently, the 2nd Paragraph of the same Section reinforces the technical profile of the Directors by providing that only "Brazilians who have an unblemished reputation, higher level of education and high concept in the field of specialty" may be nominated to that position. And yet, it also imposes on former Directors a period of "quarantine" of 6 months without engaging in 
A glass half full look at the brazilian data protection authority Leonardo Parentoni

any activities related to personal data protection after they leave the board, to prevent possible conflicts of interest (BGDPL, Section $55-\mathrm{F})$.

Therefore, in the author's view, there are enough guarantees in the BGDPL for the BDPA to perform its duties as an independent authority40. As a consequence, this authority and its members should get a vote of confidence. Other public bodies were initially structured similarly or even in a less protective manner than the BDPA and today are quite respected, such as the Administrative Council for Economic Defense - CADE41. So, it should only be expected that the BDPA can also follow the same path.

Heading out to the end of this text, it is worrisome that other issues, perhaps even more relevant than the structure of the BDPA, have not yet been treated as hot topics in the debate. One of them stands out: the potential conflict of attributions between the BDPA and other public bodies and entities ruled by ordinary law42. On the one hand, the BGDPL categorically states that the power to interpret its provisions and eventually impose sanctions belongs exclusively to the BDPA (Section 52, caput, Section 55-J, XX), emphasizing that "this power shall prevail over correlated competences of other public administration entities or administrative bodies in matters of personal data protection" (Section 55-K, caput). On the other hand, the same BGDPL encourages the BDPA to perform its regulatory duties "in accordance with other administrative bodies and entities with powers to sanction and regulate matters related to personal data protection" (Section 55-J, XXIII and Section 55-K, sole Paragraph). After all, under what circumstances will the BDPA have the final word on a particular issue if a consensus is not reached?

\footnotetext{
40 Considering as independence the sum of four factors highlighted by specialized literature: (MOREIRA NETO, 2003, p. 165): "The independence necessary to ensure that the exercise of regulatory powers is politically neutral should be understood as a content strict related to four aspects: technical, normative and managerial, budgetary and financial independence of managers."

41 Recalling that the CADE was created in 1962 by Law $n^{\circ} 4173 / 1962$ as an administrative body inside the Ministry of Justice, being transformed into an autarchy (agency) only in 1994 by Law $n^{\circ} 8884 / 1994$, which was latter repealed by Law $n^{\circ} 12529 / 2011$, currently in effect.

42 This kind of conflict does not pose a problem in case one of the institutions involved is provided for in the Constitution itself, since the constitutional rules must prevail. The same cannot be said about institutions provided for only in regular laws. See: (BOBBIO, 1999).
} 
A glass half full look at the brazilian data protection authority

This question is much more complex than it seems at first sight. It is wrong to simply assume that the BDPA position will always prevail. Indeed, the interaction between regulatory bodies is partially disciplined in Law $n^{\circ} 13848 / 2019$ and long before that, it had already been subject of intense administrative struggle, which was later converted into the judicial matter well-known as case BACEN (Brazil's Central Bank) v. CADE (Administrative Council for Economic Defense)43. That case discussed which of these public agencies would have the final word in analyzing the lawfulness of a merge involving financial institutions. The opinion of the Federal Attorney General, later confirmed by the Superior Court of Justice, stated that the principle of specialty must be applied. Therefore, BACEN had the final word in deciding whether the merger was lawful as it is a more specialized institution in the National Financial System than CADE, which analyzes the competition as a whole, encompassing a variety of economic sectors and players.

Following this reasoning, in the context of personal data protection, one can imagine that in case of a conflict between the BDPA and sectoral regulatory agencies, decisions of the latter will prevail. And this is not just hypothetical or far from reality. On the contrary, in the case of cloud banking44, for example, a linear application of what was ruled would lead to the conclusion that the final decision would be BACEN's instead of the BDPA's. The issue involves deepening insights and important distinctions that could affect the conclusion, but it is not the case of addressing them here for the sake of brevity.

Another issue of paramount importance and that still lacks proper studies is the relationship between the BGDPL and other laws that sparsely address personal data protection, such as the Consumer Protection Code and the Brazilian Civil Framework of the Internet ${ }^{45}$.

\footnotetext{
43 See also: STJ, 1st Section, Special Appeal no 1.094.218/DF, j. 25.08.2010, Rel. Ministra Eliana Calmon.

44 In short, cloud banking is the transference of personal data controlled by financial institutions from their traditional data processing and storage centers, where each institution is responsible for its own center, to a cloud storage service run by third parties. This subject is currently regulated by BACEN Resolution $n^{\circ} 4658 / 2018$.

45 On this topic, see the paper written by this author in January 2019, which, as far as it's known, was one of the first - if not the first Brazilian author - to address this subject: (PARENTONI, 2020).
} 


\section{Final Remarks}

It is indisputable that the BDPA does not have the ideal structure inspired by the European model. For this reason, it was subjected to intense criticism as if doomed to fail. This study intended to provide a different and more optimistic overview, demonstrating that the BDPA already has enough guarantees to act as an independent authority. The author opted for looking at the glass "half full" instead of seeing it "half-empty". Accordingly, the effectiveness and success of the BDPA will depend more on the ability of its first Directors than on the static structure provided by law. In this context, more important than criticizing the BDPA's structure is to contribute to its functioning - and watch over it -, to ensure that it will, in fact, fulfill its important mission. Especially in the current scenario of economic crisis, where the solutions adopted are usually not the ideal ones but those that are feasible.

To come to this conclusion, the author has carried out a structuralist analysis comparing the Brazilian BDPA with its Uruguayan equivalent, the URCDP. He demonstrated that the URCDP is very similarly structured to the Brazilian authority and it has been acting for over more than a decade quite successfully. This corroborates with the assumption that even more important than structure is how the authority performs its duties in practice. And at this point, at least for now, there are not enough scientific basis to question the BDPA, since it has not even started performing its activities.

What everyone hopes is that the BDPA will be a success and contribute decisively to the improvement of the culture of personal data protection in Brazil. To achieve that goal, it deserves an initial vote of confidence. As the Brazilian writer Ariano Suassuna once said: "The optimist is a fool; the pessimist is dull; the good thing is to be hopefully realistic."

Finally, since the current structure of the BDPA is already consolidated it would be advisable to broaden the debate to other issues of paramount importance, although not yet in the spotlight. 
A glass half full look at the brazilian data protection authority

For example, the potential conflict of attributions between the BDPA and other public bodies and entities ruled by ordinary law, such as the relationship between the BGDPL and other laws that sparsely address personal data protection, such as the Consumer Defense Code and the Brazilian Civil Framework of the Internet.

\section{References}

BIONI, Bruno Ricardo. Privacidade e proteção de dados pessoais em 2019. Jota, 28 jan. 2019. Available at: <https://www. jota.info/paywall?redirect_to=//www.jota.info/opiniao-e-analise/ colunas/agenda-da-privacidade-e-da-protecao-de-dados/privacidade-e-protecao-de-dados-pessoais-em-2019-28012019>. Access: 29 Jul. 2019.

BOBBIO, Norberto. Da Estrutura à Função: Novos Estudos de Teoria do Direito. Tradução: Daniela Beccaccia Versiani. Barueri: Manole, 2007.

BOBBIO, Norberto. Teoria do Ordenamento Jurídico. 10. ed. Brasília: Universidade de Brasília, 1999.

BRAZIL. Câmara dos Deputados. Projeto de Lei n 5.276/2016. Available at: <http://www.camara.gov.br/proposicoesWeb/ fichadetramitacao?idProposicao=2084378>. Access: 08 Dec. 2018.

BRAZIL. Câmara dos Deputados. Presidência da República.

Mensagem de Veto n. 451/2018. Available at: <http://www.planalto.gov.br/ccivil_03/_Ato2015-2018/2018/Msg/VEP/VEP-451.htm>. Access: 07 Dec. 2018.

BRUNET, Laura Nahabetián. Del Gobierno Electrónico al Gobierno de la Información. Montevideo: Amalio M. Fernández Editorial y Librería Jurídica, 2015.

COUNCIL OF EUROPE. Convention for the Protection of Individuals with regard to Automatic Processing of Personal 
Data. Strasbourg: 28 Jan. 1981. Available at: <https://www.coe. int/en/web/conventions/full-list/-/conventions/treaty/108/signatures>. Access: 30 Jul. 2019.

COUNCIL OF EUROPE. Cooperação internacional. Available at: $<$ https://edpb.europa.eu/international-cooperation_pt>. Access: 31 Jul. 2019.

DIGITAL 9. About the D9. Available at: <https://www.digital.govt. nz/digital-government/international-partnerships/the-digital-9/>. Access: 31 Jul. 2019.

DONEDA, Danilo Cesar Maganhoto. Da privacidade à proteção e dados pessoais. Rio de Janeiro: Renovar, 2006.

DONEDA, Danilo Cesar Maganhoto. Rumo à Autoridade Nacional de Proteção de Dados. In: DE LUCCA, Newton; SIMÃO FILHO, Adalberto; LIMA, Cíntia Rosa Pereira de; MACIEL, Renata Mota (Coord.). Direito \& Internet IV: Sistema de Proteção de Dados Pessoais. São Paulo: Quartier Latin, 2019.

HOPT, Klaus. Uma Conversa sobre Direito Societário Comparado com o Professor Klaus Hopt. Cadernos Direito GV. São Paulo: Direito GV, v. 6, n. ${ }^{\circ}$ 2, mar. 2009.

LYNSKEY, Orla. The Foundations of EU Data Protection Law. Oxford: Oxford University Press, 2015.

MENDES, Laura Schertel; et al. Methodology for Comparative Law Analysis on Personal Data Legal Protection. Proceedings of the $\mathbf{2 0 1 9}$ Communication Policy Research Latin America - CPRLATAM. Cordoba: Americas Information and Communications Research Network. p. 141-162, Jul. 2019. MOREIRA NETO, Diogo de Figueiredo. Direito Regulatório. Rio de Janeiro: Renovar, 2003.

NOUGRÈRES, Ana Brian. Uruguay y la Protección de Datos Personales. In: DE LUCCA, Newton; SIMÃO FILHO, Adalberto; LIMA, Cíntia Rosa Pereira de; MACIEL, Renata Mota (Coord.). 
Direito \& Internet IV: Sistema de Proteção de Dados Pessoais. São Paulo: Quartier Latin, 2019.

PARENTONI, Leonardo. Protection of Personal Data in Brazil: Internal Antinomies and International Aspects. In: LIMA, Cíntia Rosa Pereira de (Coord.). Comentários à Lei Geral de Proteção de Dados: Lei n. 13.709/2018, com alteração da Lei n. 13.853/2019. São Paulo: Almedina, 2020.

PFEIFFER, Roberto Augusto Castellanos. A Saga da Autoridade Nacional de Proteção de Dados: Do veto à Lei n 13.853/2019. In: DE LUCCA, Newton; SIMÃO FILHO, Adalberto; LIMA, Cíntia Rosa Pereira de; MACIEL, Renata Mota (Coord.). Direito \& Internet IV: Sistema de Proteção de Dados Pessoais. São Paulo: Quartier Latin, 2019.

PSCHEIDT, Kristian. Lei de Proteção de Dados: de agência para órgão, a mudança é muito maior, analisa Kristian Pscheidt. Poder 360, 28 jul. 2019. Available at: <https://www.poder360.com.br/ opiniao/governo/lei-de-protecao-de-dados-de-agencia-paraorgao-a-mudanca-e-muito-maior-analisa-kristian-pscheidt/>. Access: 29 jul. 2019.

RIPERT, Georges. Aspectos Jurídicos do Capitalismo Moderno. Campinas: Red, 2002.

\section{SARMENTO E CASTRO, Catarina. Direito da Informática,}

Privacidade e Dados Pessoais. Coimbra: Almedina, 2005.

SOPRANA, Paula. Temer cria autoridade de proteção de dados vinculada à Presidência. Folha de São Paulo, 28 dez. 2018. Available at: <https://www1.folha.uol.com.br/mercado/2018/12/ temer-cria-autoridade-de-protecao-de-dados-vinculada-a-presidencia.shtml>. Access: 29 Jul. 2019.

TENE, Omer. Privacy Law's Midlife Crisis: A Critical Assessment of the Second Wave of Global Privacy Laws. Ohio State Law Journal. Columbus: Moritz College of Law. v. 74, n. 06, p. 12171261, Nov. 2013. 
THE EUROPEAN UNION. Comissão Europeia. Decisão de Execução da Comissão. Bruxelas: 21 ago. 2012. Available at: <https://eur-lex.europa.eu/legal-content/PT/ ALL/?uri=CELEX\%3A32012D0484>. Access: 30 Jul. 2019.

THE UNITED STATES OF AMERICA. Federal Trade Commission - About the FTC. Available at: <https://www.ftc.gov/about-ftc>. Access: 27 Jul. 2019.

THE UNITED STATES OF AMERICA. Federal Trade Commission News \& Events. Available at: <https://www.ftc.gov/news-events/ press-releases/2019/07/ftc-imposes-5-billion-penalty-sweeping-new-privacy-restrictions>. Access: 27 Jul. 2019.

TIKKINEN-PIRI, Christina; ROHUNEN, Anna; MARKKULA, Jouni. EU General Data Protection Regulation: Changes and implications for personal data collecting companies. Computer Law \& Security Review. Amsterdam: Elsevier. v. 34, n. 01, p. 134-153, Feb. 2018.

URUGUAY. Agencia para el Desarrollo del Gobierno de Gestión Electrónica y la Sociedad de la Información y del Conocimiento - AGESIC. Available at: <https://www.gub.uy/agencia-gobierno-electronico-sociedad-informacion-conocimiento/ comunicacion/noticias/nuevos-datos-resultados-de-la-5a-encuesta-de-conocimientos-actitudes-y>. Access: 01 Aug. 2019.

URUGUAY. Instituto Nacional de Estadística. Available at: <http://www.ine.gub.uy/inicio>. Access: 31 Jul. 2019. In relation to Brazil see: BRAZIL. Instituto Brasileiro de Geografia e Estatística. Available at: <https://www.ibge.gov.br/>. Access: 31 Jul. 2019.

\section{URUGUAY. Unidad Reguladora y de Control de Datos} Personales - Estadísticas. Available at: <https://www.gub.uy/ unidad-reguladora-control-datos-personales/datos-y-estadisticas/ estadisticas>. Access: 01 Aug. 2019.

URUGUAY. Unidad Reguladora y de Control de Datos Personales. Informe a 10 años de la Ley de Protección de Datos 
A glass half full look at the brazilian data protection authority

Personales. Revista Uruguaya de Protección de Datos Personales. Montevideo: URCDP. n. 03, p. 85-98, Oct. 2018. Available at: $<$ https://www.gub.uy/unidad-reguladora-control-datos-personales/comunicacion/publicaciones/revista-de-proteccion-de-datos-personales-3era-edicion-2018>. Access: 01 Aug. 2019.

VALENTE, Jonas. Autoridades e pesquisadores debatem adoção da lei de proteção de dados. Agência Brasil, 18 jun. 2019. Available at: <http://agenciabrasil.ebc.com.br/politica/ noticia/2019-06/autoridades-e-pesquisadores-debatem-adocao-da-lei-de-protecao-de-dados>. Access: 29 Jul. 2019.

VASCONCELOS, Beto; DE PAULA, Felipe. A autoridade nacional de proteção de dados: origem, avanços e pontos críticos. In: TEPEDINO, Gustavo; FRAZÃO, Ana; OLIVA, Milena Donato (Coord.). Lei Geral de Proteção de Dados Pessoais: e suas repercussões no Direito Brasileiro. São Paulo: Revista dos Tribunais, 2019.

VENTURA, Ivan. Entenda como será a futura Autoridade Nacional de Proteção de Dados. Consumidor Moderno, 05 abr. 2019. Available at: <https://www.consumidormoderno.com. br/2019/05/01/entenda-futura-autoridade-nacional-protecao-dados/>. Access: 30 Jul. 2019.

WHITMAN, James Q. The Two Western Cultures of Privacy: Dignity versus Liberty. Yale Law Journal. Yale: The Yale Law Journal. v. 113, n. 06, p. 1151-1221, Apr. 2004. 